ORIGINAL ARTICLE / ARTIGO ORIGINAL

\title{
Factors associated with knowledge about tuberculosis and attitudes of relatives of patients with the disease in Ribeirão Preto, São Paulo, Brazil
}

\author{
Fatores associados a conhecimento sobre tuberculose e atitudes das \\ famílias de pacientes com a doença em Ribeirão Preto, São Paulo \\ Isabela Moreira de Freitas', Marcela Paschoal Popolin', Michelle Mosna Touso', \\ Mellina Yamamura', Ludmila Barbosa Bandeira Rodrigues', Marcelino Santos Neto', \\ Juliane de Almeida Crispim', Ricardo Alexandre Arcêncio'
}

\begin{abstract}
Objective: To investigate the knowledge regarding tuberculosis among relatives of patients with tuberculosis and the possible factors associated with this event and also to conduct comparative analyses between groups of relatives with or with few knowledge regarding tuberculosis, considering their attitudes in both groups. Methods: Cross-sectional study in which the sample was obtained through simple and randomized method. The data were collected by trained interviewers and validated tool. Logistic regression analyses were done using statistical software SPSS, version 22.0. Results: Among the 110 subjects recruited for the study, 85 (87.5\%) were women, and the mean age was 49 years. Regarding common symptoms of tuberculosis, 102 relatives $(90.9 \%)$ pointed the chronic cough; regarding the knowledge about tuberculosis transmission modes, 100 (90.9\%) of them pointed symptomatic respiratory as the probable infection source. The relatives also reported other tuberculosis transmission models: sharing of clothes $(\mathrm{n}=87 ; 79.1 \%)$ and household utensils $(\mathrm{n}=66 ; 60 \%)$; sexual relations $(\mathrm{n}=50 ; 50 \%)$. Illiterate relatives (adjusted OR $=4.39 ; 95 \% \mathrm{CI}$ 1.11 - 17.36), those who do not watch or watch little television (adjusted OR $=3.99 ; 95 \% \mathrm{CI} 1.2-13.26$ ), and also those who do not have the Internet access (adjusted OR $=5.01 ; 95 \%$ CI $1.29-19.38$ ) were more likely to have low knowledge regarding tuberculosis. Regardless the group, with or without tuberculosis knowledge, the attitudes of both were satisfactory. Conclusion: There are evidences that social inequity is associated to the tuberculosis knowledge of patient relatives.
\end{abstract}

Keywords: Knowledge. Tuberculosis. Attitude. Health Education. Health Services Accessibility. Social Participation.

'Nursing School of Ribeirão Preto, Universidade de São Paulo - Ribeirão Preto (SP), Brazil.

Corresponding author: Ricardo Alexandre Arcêncio. Departamento de Enfermagem Materno-Infantil e Saúde Pública, Escola de Enfermagem de Ribeirão Preto, Universidade de São Paulo. Avenida dos Bandeirantes, 3900, CEP: 14040-902, Ribeirão Preto, SP, Brazil. E-mail: ricardo@eerp.usp.br

Conflict of interests: nothing to declare - Financial support: Conselho Nacional de Desenvolvimento Científico e Tecnológico (CNPq), edital MCT/CNPq/14/2010 Universal, process 482197/20); Fundação de Amparo à Pesquisa do Estado de São Paulo (FAPESP), Master's degree scholarships (process 2011/16717-6) and Scientific Initiation (process 2011/19786-9). 
RESUMO: Objetivo: Investigar o conhecimento das famílias sobre tuberculose e os possíveis fatores associados a essa ocorrência, além de efetuar uma análise comparativa dos grupos de familiares com conhecimento ou com pouco conhecimento quanto às suas atitudes para com o paciente com tuberculose. Métodos: Estudo de corte transversal de amostragem probabilística simples de familiares de pacientes com tuberculose diagnosticados entre 01 de janeiro de 2010 e 31 de julho de 2011 em Ribeirão Preto, São Paulo. Os dados foram coletados por meio de um instrumento validado e por entrevistadores treinados. A análise de regressão logística foi aplicada utilizando o SPSS versão 22.0. Resultados: Foram recrutados 110 familiares, dos quais 85 (87,5\%) eram do sexo feminino, com idade média de 49 anos. Acerca do conhecimento dos sintomas da tuberculose, a tosse crônica foi referida por 102 (90,9\%) familiares. Quanto ao modo de transmissão, 100 (90,9\%) sujeitos referiram o portador de tosse crônica como provável fonte de transmissão. Outros modos de transmissão foram referidos como compartilhamento de roupas ( $\mathrm{n}=87 ; 79,1 \%)$; utensílios domésticos $(\mathrm{n}=66 ; 60 \%)$ e até relação sexual $(\mathrm{n}=50 ; 50 \%)$. Pessoas sem escolaridade (OR ajustado = 4,39; IC95\% 1,11 - 17,36), que não assistem ou assistem pouco televisão (OR ajustado = 3,99; IC95\% 1,20 - 13,26) e não tem acesso à Internet (OR ajustado $=5,01$; IC95\% 1,29 - 19,38) apresentaram mais chances de possuírem pouco conhecimento sobre a tuberculose. Independente do grupo com ou sem conhecimento, as atitudes tenderam a ser satisfatórias em ambos os grupos. Conclusão: Há evidências de que as desigualdades sociais estão associadas ao nível de conhecimento das famílias.

Palavras-chave: Conhecimento. Tuberculose. Atitude. Educação em saúde. Acesso aos serviços de saúde. Participação social.

\section{INTRODUCTION}

Tuberculosis (TB) is one of the main causes of death among the infectious diseases worldwide. In 2012, about 8.6 million people developed TB and 1.3 million died of it. It is worth mentioning that 2 billion people are infected with Mycobacterium tuberculosis, which represents a substantial deposit of the pathogen, therefore it established some challenges to the sanitary authorities for eliminating TB until $2050^{1}$.

Brazil is at the $16^{\text {th }}$ position in number of cases and at the $109^{\text {th }}$ position in the coefficient of incidence of TB infection. Since 1990, the number of TB cases has been decreasing in the country, and it may reach the Millennium Development Goals of reducing $50 \%$ of the disease incidence ${ }^{1}$.

Among the studies conducted in Brazi ${ }^{2-4}$, there is some evidence that the medical technological availability for diagnosis or treatment alone has not been improving in terms of access to health services.

Studies point out that cultural, environmental, and sociopolitical factors are determinant in this process ${ }^{5-7}$. According to the authors, the population's knowledge about TB is an important factor to improve the disease control ${ }^{8-11}$.

The World Health Organization (WHO) together with the Stop TB Strategy created the Advocacy, Communication and Social Mobilization (ACSM) in 2006 ${ }^{12}$, 
with the purpose of making the population aware of TB and stimulating community participation in health control. In countries like Pakistan ${ }^{13}$ and India ${ }^{11}$, promising results have been observed regarding the awareness of the population, the reduced waiting time to find services for diagnosis, the adhesion to treatment, and the decreasing social stigma.

In Brazil, this strategy was not formally and systematically introduced in health services, which prevents an evaluation addressed to the program.

It is worth mentioning that TB is a concept produced in the social imaginary of the population, therefore beliefs, values, and behaviors with regard to the disease may influence collective health projects designed to stop its aggravation. For the authors, knowledge about TB will encourage people to look for health care and quality of clinical/epidemiological results ${ }^{11}$.

However, studies about the theme in the country are rare; therefore, investigations on the possible factors associated with this event, being not explored and/or not well understood, are required ${ }^{14-16}$.

In the scope of public policies ${ }^{17}$, the improvement of new technologies is recommended with higher diagnostic sensitivity and therapies that reduce treatment time. However, some authors have reported that the awareness of a population about such an issue is what ends up defining the acceptance and the use of these technologies ${ }^{11}$.

In a literature review, we can notice the non-satisfactory level of knowledge among patients with TB in the Brazilian prison system ${ }^{18}$, noncomprehension of the meaning of treatment adhesion by relatives in the Brazilian South ${ }^{14}$, and many discriminatory attitudes that come from the lack of knowledge of communities about $\mathrm{TB}^{13}$.

Studies in Pakistan show that education, income, and housing conditions seem to explain the phenomenon ${ }^{8}$. These factors were also identified by Ali et al. ${ }^{19}$ in families of patients with the disease. Therefore, a question is raised if such factors are applied to families in Brazil. Thus, we sought to investigate the knowledge of relatives about $\mathrm{TB}$ and the possible factors associated with this occurrence, and to conduct a comparative analysis of groups of relatives with knowledge or with little knowledge about their attitudes toward the patient with TB in Ribeirão Preto, São Paulo, Brazil.

\section{METHODS}

This is a cross-sectional study performed in the municipality of Ribeirão Preto, São Paulo, Brazil, which has about 604,682 thousand residents and is classified as pole city and a reference for the neighboring locations with regard to actions in health that require high technological density. Attention to TB in the municipality is centralized in five health district unities; each of them has a Reference Center that assists the patient with TB and his/her relatives. 
The study population comprised relatives of patients diagnosed with pulmonary TB between January 1st, 2010 and July 31, 2011, aged more than 18 years old and under treatment for at least 1 month.

In the study period, 180 confirmed cases of TB were identified; among them $5(2.7 \%)$ were excluded for being in a confinement situation and $32(17.7 \%)$ for having the information of "zero communicators" in the record system (TB-WEB).

Finally, 153 cases were considered to be candidates for the investigation. We chose to work with a minimum and simple random sample without replacement. Considering a 95\% confidence level (95\%CI), 5\% tolerable sample error, $10 \%$ loss, and 50\% estimated proportion of the population $(\mathrm{p}=0.5$ ) with proper knowledge about about $\mathrm{TB}$, the established final minimum sample for the investigation was of 110 observations.

In the study for each TB case, a relative was selected. Following the authors' recommendations ${ }^{20}$, only relatives who were present at the time of interview were chosen or when there was more than a person, the first one who talked to the interviewer was selected.

Twelve items of an instrument prepared by the authors were considered for the article based on the material published by $\mathrm{WHO}^{21}$. It is important to highlight that such material is part of the ACMS Program and aims at supporting researchers and managers in the development of instruments to assess knowledge, attitudes, and practices associated with $\mathrm{TB}^{12}$.

It is worth mentioning that the instrument was submitted to content validation, in which 10 experts appraised and gave suggestions with regard to structure and content. Later on, a pretest of the instrument was performed with 10 relatives of the patients with TB to measure their cultural sensitivity and certification of comprehensibility of the study population.

The instrument dimension associated with the knowledge about the disease comprised closed matters about the causal agent of TB, favorable factors, transmission mode, signals and symptoms, period of transmission, treatment duration, and if the families had read or heard anything about TB. The respondents had to choose the answers they thought to be correct.

With regard to attitudes, items were structured on the five-point Likert scale ( 1 = never; $2=$ hardly ever; $3=$ sometimes; $4=$ almost always; and $5=$ always), and the participants filled in the frequency with which they noticed the occurrence of an event.

The questionnaire also included questions about sociodemographic conditions, such as income (open question), information sources families use to consult, if teams of the directly observed treatment (TDO) were visited, or if the relative was in the treatment for latent TB.

The team of interviewers visited the health services to present the study and update the participants' addresses. Five interviewers took part in data collection, who had been previously trained and performed house interviews between July and August, 2011.

Data were analyzed through the software STATISTICA, version 9.0 of StatSoft ${ }^{\circledR}$ and SPSS for Mac. At first, the frequency of answers regarding knowledge was surveyed, therefore 
it was possible to observe the percentage of correct and incorrect answers. The criteria for the correction of responses were based on the Health Surveillance Guide, published by the Ministry of Health ${ }^{22}$.

Afterwards, a cutoff point for correct answers was defined considering the average percentage of right answers provided by the participants; $60 \%$ meant awareness, and lower percentages meant little awareness.

A bivariate analysis was performed to test the association between knowledge by relatives (knowledge and little knowledge) and the dichotomized sociodemographic independent variables (age, income, schooling, unemployment, habit of reading newspapers, habit of watching television) and health services (being on TDO and TB latent treatments), then the $\chi^{2}$ test, $\chi^{2}$ test with Yates correction, or the Fisher's exact test was applied. The considered association measure was odds ratio (OR) and its respective $95 \% \mathrm{CI}$.

The income variable was converted into minimum wages (MWs), and the average income of families was calculated; then, the variable was dichotomized as higher or lower than average.

Later, the multiple analyses with the binary logistic regression were carried out with the manual backward-forward stepwise strategy. In this stage, the most significant variables were chosen $(\mathrm{p}<0.2)$ in the bivariate analysis.

Authors ensured significance and quality of the model by using likelihood ratio and Hosmer-Lemeshow tests. The significance level established for the permanence of variables in the model was fixed as alpha lower than $5 \%(\mathrm{p}<0.05)$, as for the other statistic tests considered in the study.

To test the mean difference between attitudes of groups with knowledge and little knowledge regarding attitudes, the authors chose the Student's $t$-test. We should mention that such a test was used when normality and homoscedasticity criteria of variance were met, which were respectively verified by the Shapiro-Wilk and the Levene tests. In case these criteria were not followed, the Mann-Whitney U-test was applied.

The mean score found in every item related to attitude of the instrument and per group was calculated through the sum of scores, dividing the number of subjects in each group. Scores higher than four were considered satisfactory; between three and four, regular; and lower than three, non-satisfactory.

The project was approved by the Research Ethics Committee of the Nursing School in Ribeirão Preto, Universidade de São Paulo. All subjects who accepted participating in the study signed the free informed consent.

\section{RESULTS}

Table 1 presents the sociodemographic characteristics of relatives analyzed in the sample. The mean number of residents living with the TB patients was 4 people with standard 
deviation (SD) of 1.79 , minimum of 1 subject and maximum of 11 . The mean age of the interviewed individuals was 49 years old $(\mathrm{SD}=16.74)$, minimum of 18 and maximum of 84. With regard to family income, most of the subjects earned between one and four MWs.

In Table 2, regarding knowledge, we can see that $32(29.2 \%)$ relatives did not know the causal agent of TB and, among the factors that favor sickness, $43(39.1 \%)$ mentioned alcoholism. As to transmission, 100 (90.9\%) relatives assuredly referred that being in the same place with a person coughing may lead to a possibility of becoming infected. However, other forms of transmission were also pointed out, in which $87(79.1 \%)$ subjects reported wearing the same clothes; $66(60 \%)$ sharing plates, flatware, and glasses; 61 (55.5\%) mentioned contaminated water; and 50 (50\%) reported sexual intercourse.

Table 1. Sociodemographic characteristics of relatives and family relation with tuberculosis subjects, Ribeirão Preto, SP, Brazil, 2011.

\begin{tabular}{|c|c|c|}
\hline Variables & $n$ & $\%$ \\
\hline \multicolumn{3}{|l|}{ Age (years) } \\
\hline $18-29$ & 18 & 16.3 \\
\hline $30-59$ & 63 & 57.2 \\
\hline$\geq 60$ & 29 & 26.5 \\
\hline \multicolumn{3}{|l|}{ Sex } \\
\hline Male & 25 & 22.5 \\
\hline Female & 85 & 87.5 \\
\hline \multicolumn{3}{|l|}{ Occupation } \\
\hline Retired & 24 & 21.8 \\
\hline Unemployed & 13 & 11.8 \\
\hline Housework & 24 & 21.8 \\
\hline Others & 49 & 44.5 \\
\hline \multicolumn{3}{|l|}{ Income } \\
\hline$\leq 1$ minimum wage* & 26 & 23.6 \\
\hline $1-4.9$ minimum wage & 64 & 58.1 \\
\hline$\geq 5$ minimum wage & 20 & 18.1 \\
\hline \multicolumn{3}{|l|}{ Schooling } \\
\hline No schooling & 12 & 10.9 \\
\hline Elementary school & 59 & 53.6 \\
\hline High school & 33 & 30.0 \\
\hline Superior school & 06 & 5.4 \\
\hline \multicolumn{3}{|l|}{ Family association } \\
\hline Grandparents & 5 & 4.5 \\
\hline Husband/wife & 26 & 23.6 \\
\hline Son/daughter & 12 & 10.9 \\
\hline Sister/brother & 18 & 16.3 \\
\hline Parents & 32 & 29.0 \\
\hline Uncle/aunt & 04 & 3.6 \\
\hline Others & 13 & 11.8 \\
\hline
\end{tabular}

*The current minimum wage at the time of data collection was BRL 545.00. 
Coughing was acknowledged as being the most common symptom by $102(92.7 \%)$ participants, whereas $100(90.9 \%)$ relatives reported pain in the chest, $96(87.3 \%)$ mentioned weight loss, and $86(78.2 \%)$ referred to loss of appetite. As to the period

Table 2. Tuberculosis knowledge between relatives of patients with the disease $(n=110)$ in Ribeirão Preto, SP, Brazil, 2011.

\section{Variables}

Tuberculosis germ

\begin{tabular}{l|l|}
\hline Virus & \\
\hline Bacteria & \\
\hline Does not know & \\
\hline Others &
\end{tabular}

Factors that favor disease development

\begin{tabular}{l|l|}
\hline Alcoholism & \\
\hline Others & \\
\hline HIV & \\
\hline Does not know & \\
\hline History in the family & \\
\hline Diabetes
\end{tabular}

Modes of transmission seen by the families*

\begin{tabular}{|l|l|l|}
\hline When the person coughs and if he/she is in the same place & 100 & 90.9 \\
\hline
\end{tabular}

Using the same cloth

Common use of plates, flatware, and glasses

Contaminated water

Sexual intercourse

$43 \quad 39$

$28 \quad 25.5$

$25 \quad 22.7$

$10 \quad 9.1$

$03 \quad 2.7$

$01 \quad 0.9$

Seen signals and symptoms*

\begin{tabular}{|l|l|l}
\hline Cough & 102 & 92.7 \\
\hline Pain in the chest and back & 100 & 90.9 \\
\hline Weight loss & 96 & 87.3 \\
\hline Appetite loss & 86 & 78.2 \\
\hline Cephalea & 65 & 59.1 \\
\hline Night sweating & 45 & 40.9 \\
\hline Leg swallow & 17 & 15.5 \\
\hline Stains in the body & 10 & 9.1 \\
\hline Transmissibility period after beginning of treatment & & 48.2 \\
\hline Others & 53 & 33.6 \\
\hline Does not know & 37 & 18.2 \\
\hline 2 weeks (correct) & 20 & \\
\hline Duration of treatment & & 64.5 \\
\hline 6 months (correct) & 71 & 23.6 \\
\hline Others & 26 & 11.8 \\
\hline Does not know & 13 & \\
\hline Has read or heard information about tuberculosis & 101 & 91.8 \\
\hline Yes & 09 & 8.2 \\
\hline No & & \\
\hline
\end{tabular}

*Non-mutually exclusive questions with the possibility of more than one answer. 
of transmission after the onset of regular therapy, only $20(18.2 \%)$ relatives responded correctly and $37(33.6 \%)$ did not know the answer. As to the duration of treatment, $71(64.5 \%)$ relatives reported 6 months, which corresponded to the correct sentence. It is important to mention that $101(91.8 \%)$ participants had already read or heard pieces of information about the disease.

Table 3 compares groups of relatives with knowledge or little knowledge about TB. The following variables were statistically significant in the bivariate analysis: being more than 51 years old $(\mathrm{p}=0.02)$, without schooling $(\mathrm{p}=0.009)$, not reading

Table 3. Bivariate analysis of factors associated with knowledge on tuberculosis by relatives of patients with the disease in Ribeirão Preto, SP, Brazil, 2011.

\begin{tabular}{|c|c|c|c|c|c|c|c|}
\hline \multirow{2}{*}{ Variables } & \multicolumn{2}{|c|}{ Knowledge } & \multicolumn{2}{|c|}{ Little knowledge } & \multicolumn{2}{|c|}{ Bivariate analysis } & \multirow{2}{*}{ p-value } \\
\hline & $\mathrm{n}$ & $\%$ & $\mathrm{n}$ & $\%$ & Crude OR & $95 \% \mathrm{Cl}$ & \\
\hline \multicolumn{8}{|l|}{ Age (years) } \\
\hline$\leq 51$ & 46 & 55.4 & 8 & 29.6 & 1 & - & \\
\hline$>51$ & 37 & 44.6 & 19 & 70.4 & 2.95 & $1.16-7.50$ & $0.02^{*}$ \\
\hline \multicolumn{8}{|l|}{ Schooling } \\
\hline Yes & 78 & 94 & 20 & 74.1 & 1 & - & - \\
\hline No & 5 & 6 & 7 & 25.9 & 5.46 & $1.56-19.02$ & $0.009^{*}$ \\
\hline \multicolumn{8}{|l|}{ Job situation } \\
\hline Employed & 72 & 86.7 & 25 & 92.6 & 1 & - & \\
\hline Unemployed & 11 & 13.3 & 2 & 7.4 & 0.52 & $0.10-2.52$ & 0.51 \\
\hline \multicolumn{8}{|l|}{ Income (MW) } \\
\hline$>1.8$ & 40 & 48.2 & 12 & 44.4 & 1 & - & \\
\hline$\leq 1.8$ & 43 & 51.8 & 15 & 55.6 & 1.16 & $0.48-2.78$ & 0.73 \\
\hline \multicolumn{8}{|l|}{ Reading newspapers } \\
\hline Yes & 53 & 63.9 & 9 & 33.3 & 1 & - & \\
\hline No & 30 & 36.1 & 18 & 66.7 & 3.53 & $1.41-8.83$ & $0.005^{*}$ \\
\hline \multicolumn{8}{|l|}{ Watching television } \\
\hline A lot & 73 & 88 & 19 & 70.4 & 1 & - & \\
\hline Never or hardly ever & 10 & 12.0 & 08 & 29.6 & 3.07 & $1.06-8.85$ & $0.041^{*}$ \\
\hline \multicolumn{8}{|l|}{ Internet access } \\
\hline Yes & 34 & 41 & 03 & 11.1 & 1 & - & \\
\hline No & 49 & 59 & 24 & 88.9 & 5.55 & $1.54-19.91$ & $0.04^{*}$ \\
\hline \multicolumn{8}{|c|}{ Directly observed treatment } \\
\hline Yes & 70 & 84.3 & 24 & 88.9 & 1 & - & \\
\hline No & 14 & 15.7 & 3 & 11.1 & 0.67 & $0.17-2.56$ & 0.757 \\
\hline \multicolumn{8}{|l|}{ In latent TB treatment } \\
\hline Yes & 15 & 18.1 & 5 & 18.5 & 1 & - & \\
\hline No & 68 & 81.9 & 22 & 81.5 & 0.97 & $0.31-2.97$ & 1.000 \\
\hline
\end{tabular}

*Variables with $\mathrm{p}<0.20$ were included in the multiple regression analysis; OR: odds ratio; $95 \% \mathrm{Cl}$ : $95 \%$ confidence interval; MW: current minimum wage at the time of data collection (BRL 545.00). 
newspapers $(0.005)$, not watching or watching very little television $(\mathrm{p}=0.041)$, and not having access to the Internet $(\mathrm{p}=0.04)$.

These variables were taken to logistic regression (Table 4), confirming that people with no schooling (adjusted OR $=4.39$; 95\%CI $1.11-17.36$ ), who do not watch or watch very little television (adjusted OR $=3.99 ; 95 \% \mathrm{CI} 1.20-13.26$ ), and with no Internet access (adjusted OR $=5.01 ; 95 \%$ CI $1.29-19.38$ ) have more chances of knowing little about TB. According to the likelihood function, such a model is significant $(\mathrm{p}<0.001)$, with good adaptation according to the Hosmer-Lemeshow test $\left(\chi^{2}=3.97 ; \mathrm{p}=0.554\right)$. The Cox and Snell and the Nagelkerke tests consider that the established model was able to explain 18.4 and $27.4 \%$, of the variations registered in the little knowledge variable, respectively.

In Table 5, by crossing the variable attitudes of the families and the variable groups with awareness or little awareness about TB, no statistically significant differences were found concerning their means. In both groups, a similar pattern of responses was observed, and

Table 4. Multiple logistic regression analysis of factors associated with few knowledge about tuberculosis by relatives of patients with the disease in Ribeirão Preto, SP, Brazil, 2011.

\begin{tabular}{l|c|c|c}
\hline Variables & Adjusted OR* & $95 \% \mathrm{Cl}$ & $\mathrm{p}$-value \\
\hline Age above 51 years old & 1.07 & $0.330-3.45$ & 1.068 \\
\hline No schooling & 4.39 & $1.11-17.36$ & $0.035^{* *}$ \\
\hline Not watching or watching less television & 3.99 & $1.20-13.26$ & $0.024^{* *}$ \\
\hline Not reading newspaper & 2.22 & $0.75-6.52$ & 0.156 \\
\hline Not accessing the Internet & 5.01 & $1.29-19.38$ & $0.019^{* *}$
\end{tabular}

*OR: Odds ratio adjusted for age, schooling, and sources of information; $95 \% \mathrm{Cl}$ : $95 \%$ confidence interval; ** $<<0.05$ value.

Table 5. Attitudes of relatives according to their level of knowledge on tuberculosis in Ribeirão Preto, SP, Brazil, 2011.

\begin{tabular}{|c|c|c|c|}
\hline \multirow[b]{2}{*}{ Attitudes } & \multicolumn{2}{|c|}{ Knowledge about tuberculosis } & \multirow[b]{2}{*}{ p-value } \\
\hline & $\begin{array}{l}\text { Mean } \pm S D \\
(n=27)\end{array}$ & $\begin{array}{l}\text { Mean } \pm \text { SD } \\
(n=83)\end{array}$ & \\
\hline Embarrassment toward the relative disease & $4.53 \pm 1.14$ & $4.71 \pm 0.95$ & 0.43 \\
\hline $\begin{array}{l}\text { Hides from relatives, friends, and neighbors } \\
\text { that the relative has tuberculosis }\end{array}$ & $4.07 \pm 1.46$ & $4.23 \pm 1.43$ & 0.61 \\
\hline $\begin{array}{l}\text { Avoids talking about tuberculosis in the } \\
\text { presence of other relatives and friends }\end{array}$ & $3.18 \pm 1.85$ & $3.77 \pm 1.58$ & 0.10 \\
\hline $\begin{array}{l}\text { Reported embarrassment of going out with the } \\
\text { patient with tuberculosis }\end{array}$ & $4.78 \pm 0.98$ & $4.89 \pm 0.50$ & 0.14 \\
\hline $\begin{array}{l}\text { Reported fear of being identified in the } \\
\text { institution where the relative is being treated }\end{array}$ & $4.75 \pm 0.84$ & $4.72 \pm 0.85$ & 0.87 \\
\hline
\end{tabular}

SD: standard deviation. 
most of them were satisfactory (higher than 4). Although differences between groups were not statistically significant, it was observed that the variable "avoid talking about TB in the presence of other friends and relatives" found regular scores, being much lower than the other investigated variables.

\section{DISCUSSION}

We tried to investigate the knowledge of families regarding TB and associated factors, besides the attitudes of groups of relatives with different levels of awareness about the disease. Results showed that knowledge presented a significant statistical association with education and access to information. It was also verified that attitudes of relatives did not differ as to their level of knowledge about the disease, with satisfactory answers, whether the relatives had knowledge or little knowledge.

Still with regard to knowledge, the study results showed that most families recognized cough as an important symptom of the disease and reported other symptoms such as weight loss, pain in the chest, and night sweats. These results are in agreement with the study carried out with families in Pakistan ${ }^{19}$, however, a study in Ethiopia with the community observed a lower proportion of people who recognized these symptoms ${ }^{7}$.

It was also observed that even though families emphasized people who have chronic cough as potential sources of transmission, they also referred to the common use of clothes and domestic appliances. Similar results were found by Ali et al. ${ }^{19}$ and Bati et al. ${ }^{7}$, and that raises the question about the isolation and segregation patients may be subjected to due to the incorrect perception of the families with respect to the mode of transmission.

Patient isolation has been described in systematic reviews ${ }^{23}$ as a favorable factor to treatment abandonment and discontinuity. It is important to mention that $96 \%$ of the cases of tuberculostatic multidrug resistance in Brazil happen due to the acquired form ${ }^{24}$, that is, the nonadhesion to the prescribed therapeutic regimens. Thus, working on the awareness of these families may have an impact on the adhesion and on the success of the patient's treatment.

With regard to the period of transmission, only $20 \%$ of the relatives answered correctly. Such a result leads to the matter of health surveillance: if the subjects do not identify the critical period of the treatment, they may still be exposed to bacilliferous sources, thus increasing their chances of infection by time of exposure ${ }^{25}$. Interruption of the transmission chain as soon as possible is recommended, so that health promotion actions should be introduced for the relatives'self-care, ensuring safety and salubrity at home ${ }^{25}$.

There are also other implications related to not being aware of the transmission period, as demonstrated in a study in Pakistan, in which the community isolated a patient with TB not only during the TB treatment, but also after its conclusion ${ }^{26}$. 
Also with regard to the disease symptoms, families knew how to answer correctly about the treatment duration. The number of right answers was higher than the results found by Ali et al. ${ }^{19}$.

Among the predictive factors to getting sick, alcoholism was the one families mentioned the most, maybe because it is a more common problem in their contexts and noticeable for the community. A systematic review carried out by Lönnroth et al. ${ }^{27}$ also pointed out alcoholism as a risk factor for the development of TB; however, HIV is the most common factor described in medical literature ${ }^{28}$. Among the different explanatory TB models, the social determinant theory seems to make more sense, because there is not only one isolated factor that determines it, but multiple factors, ranging from life conditions to opportunities to access health services ${ }^{29}$.

The findings also showed that $91.8 \%$ of the sample had read or heard pieces of information about TB, which is higher than the number found by Sreeramareddy et al. ${ }^{11}$, $89.3 \%$ in the Indian general population. Such results could have been even higher, because families were those who talked about the patients with TB.

Although the previously reported results showed positive aspects with regard to the awareness of families concerning symptoms and the time of treatment, with the exception of modes of transmission, there are fewer individuals $(n=27)$ with incipient knowledge about TB. People with low schooling and restricted access to information were more prone to basic knowledge.

These results indicate an issue, that is, the impact of the disease is more negative on people living in social inequality in terms of income and schooling, being more exposed to infection, for they are living in areas without ventilation and with great crowds. This population also experiences situations of late diagnosis and treatment, errors, and also uses alternative resources to the detriment of those offered by health services; They also tend to present low adhesion and, therefore, more unfavorable treatment results ${ }^{29}$.

Raising the community awareness about the disease through educational actions of health promotion is one of the several strategies created to face the problem. Turk et al. ${ }^{9}$ showed important progress in Pakistani communities after TB began be debated in the media through radio, television, and newspapers, among others.

In the same country, the ACSM program was introduced in 2007 with resources from the Global Fund; besides broadcasting mass information about the disease, part of the program was focused on sensitizing journalists, political leaders, and health professionals to the TB issue.

In Brazil, an experience began between 2008 and 2009, supported by the Global Fund, whose symbol brought the picture of a "windmill" by the association of its movement with air circulation; it was mostly present in the aforementioned years. With Brazil leaving the group of benefits from this agency, the Ministry of Health assumed the responsibility for these services $^{30}$. It is worth mentioning that media access was related to knowledge, which may have been triggered by the investments. 
This result may also be explained by the fact that relatives of the patients are under treatment; thus, their families are acquiring knowledge throughout the course of treatment by professionals' guidance and by previous knowledge learned at school or shown by campaigns in the city.

However, such an awareness may be related to common sense, without any scientific criterion $^{23}$, which may have some impact on the quality of life and on the patient's treatment, like the segregations due to the lack of acknowledgement regarding how the disease is transmitted.

Thus, it is important that the broadcasted information can turn into knowledge in different social layers, leading to changes in behaviors and attitudes. For such, Hargreaves et al. ${ }^{29}$ proposed a more structured model of social protection, with stronger educational projects and public improvement policies in terms of income distribution and generation.

A report from the Health Pan-American Organization ${ }^{31}$ showed advances of the country toward this direction; nevertheless, social inequalities are still persistent, and we can notice a gap between the rich and the poor; the white, the black, and the indigenous; the urban and the rural areas; and men and women. The report emphasized outcomes achieved by the Brazilian Unified Health System and the Bolsa Familia Program (PBF).

The study did not verify if the families with little knowledge about TB were covered by the PBF; thus, it would be interesting to provide this result in further investigations, so the impact of the program can be also observed as to knowledge. Another result is that there is no evidence that TDO can contribute with the families' awareness, maybe because there are other explanatory variables, such as the centrality of attention to the patient and not to the family, as stated in other investigations conducted in the state of São Paulo ${ }^{32}$.

Being in latent treatment of TB also did not imply knowledge, which is a concern, because these are relatives who are at high risk of becoming sick. If they are not fully aware, there may be treatment discontinuity and abandonment, thus this would be an important theme to be investigated in further studies.

With regard to attitudes, regardless of the level of knowledge, it could be seen that families tend to manifest satisfactory attitudes as to the patient with TB, which was also observed in another study ${ }^{19}$. Another aspect shown in the study was that families avoid talking about TB in the presence of friends or other people. With this result, we can assume that they avoid the subject, in a certain way, embarrasses them due to the social stigma it carries ${ }^{33}$.

Studies show that discriminatory attitudes due to TB have great influence on the clinical horizon of the disease, because patients may not look for a diagnosis and refuse the prescribed therapies $^{5,7}$. This has an impact on the community, because such people may keep on transmitting TB, with drug resistance getting worse ${ }^{34}$.

Nevertheless, the study did not find any discriminatory attitude from families toward the patients, showing much support and continuity of care. A remark that 
must be registered, however, which has already been documented in another study about attitudes, is that the answers provided by the participants may be those socially acceptable and do not reflect accurately their points of view ${ }^{35}$. Such bias is difficult to control in studies using the object.

The limitation of the present investigation is that it is a cross-sectional study; therefore, there are common biases to this kind of study, such as of information, memory, and reverse causality. Another limitation is the idea of awareness, which has several definitions; so, it is difficult to measure, especially using the questionnaire. In addition, in this study, the effect of treatment time on families' awareness regarding TB was not seen, which should be studied in further investigations with longitudinal perspective. We should highlight that $\mathrm{WHO}^{21}$ has valued studies with this theme to show scientific evidence on the problem and the importance of sanitation awareness about TB.

The offer of technology to diagnose and treat TB alone does not support an improvement project for the access to services; it is important to match them and mobilize new partnerships, such as television media, computer services, and cybernetics to spread information about the disease.

A recent published investigation calls the attention to new configurations of health systems in the post-2015 world agenda ${ }^{36}$, which are bolder, more complex, interactive, dynamic, and evolving with the society itself, incorporating other technologies toward a more resolute health care, with more significant results. With these innovations, it is certain that Brazil will reach the goals of eliminating the disease until 2050.

\section{CONCLUSION}

The study showed a satisfactory level of awareness of the families with regard to mode of transmission, symptoms, and duration of treatment. There were some errors especially concerning the mode of transmission, such as associating the disease transmission to the common use of glasses, flatware, clothes, or even sexual intercourse. However, the subject with chronical cough was highly referred to as a source of infection.

As to the associated factors, we found that people with no schooling, those who do not watch or watch very little television, and the ones who do not have access to the Internet present higher chances of being little aware of TB. Regardless of the level of knowledge by the families, their attitudes toward TB patients had a tendency of being satisfactory. There is no evidence that TDO is associated with the families' knowledge.

It is important that studies with the same subject be further investigated to subsidize managers and professionals as to evidence about the analyzed issue, and about how much the knowledge of a community with regard to a disease influences results of actions produced by health services, thus collaborating in the implementation of TB elimination goals. 


\section{REFERENCES}

1. World Health Organization (WHO). Global tuberculosis report 2013. Geneva: WHO; 2013.

2. Wysocki AD, Ponce MAZ, Scatolin BE, Andrade RLP, Vendramini SHF, et al. Atraso na procura pelo primeiro atendimento para o diagnóstico da tuberculose. Rev Esc Enferm USP 2013; 47(2): 440-7.

3. Nogueira JA, Trigueiro DRSG, Sá LD, Silva CA, Oliveira LCS, Villa TCS, et al. Enfoque familiar e orientação para a comunidade no controle da tuberculose. Rev Bras Epidemiol 2011; 14(2): 207-16.

4. Scatena LM, Villa TCS, Ruffino Netto A, Kritski AL, Figueredo TMRM, Vendramini SHF, et al. Dificuldades de acesso a serviços de saúde para diagnóstico de tuberculose em municípios do Brasil. Rev Saúde Pública 2009; 43(3): 389-97.

5. Abebe G, Deribew A, Apers L, Woldemichael K, Shiffa J, Tesfaye M, et al. Knowledge, health seeking behavior and perceived stigma towards tuberculosis among tuberculosis suspects in a rural community in southwest Ethiopia. PLoS One 2010; 5(10): e13339.

6. Anochie PI, Onyeneke EC, Onyeozirila AC, Igbolekwu LC, Onyeneke BC, Ogu AC. Evaluation of public awareness and attitude to pulmonary tuberculosis in a Nigerian rural community. Germs 2013; 3(2): 52-62.

7. Bati J, Legesse M, Medhin G. Community's knowledge, attitudes and practices about tuberculosis in Itang Special District, Gambella Region, South Western Ethiopia. BMC Public Health 2013; 13: 734.

8. Mushtaq UM, Majrooh MA, Ahmad W, Rizwan M, Luqman MQ, Aslam MJ, et al. Knowledge, attitudes and practices regarding tuberculosis in two districts of Punjab, Pakistan. Int J Tuberc Lung Dis 2010; 14(3): 303-310.

9. Turk T, Newton FJ, Netwon JD, Naureen F, Bokhari J. Evaluating the efficacy of tuberculosis Advocacy, Communication and Social Mobilization (ACSM) activities in Pakistan: a cross-sectional study. BMC Public Health 2013; 13: 887.

10. Nglazi MD, Bekker LG, Wood R, Shey MS, Uthman OA, Wiysonge CS. The impact of mass media interventions on tuberculosis awareness, health-seeking behaviour and health service utilization: a systematic review protocol. BMJ Open 2014; 4(1): e004302.

11. Sreeramareddy CT, Harsha Kumar HN, Arokiasamy JT. Prevalence of self-reported tuberculosis, knowledge about tuberculosis transmission and its determinants among adults in India: results from a nation-wide cross-sectional household survey. BMC Infect Dis 2013; 13: 16.
12. World Health Organization (WHO). Advocacy, communication and social mobilization (ACSM) for tuberculosis control: a handbook for country programmes. Geneva: WHO; 2007.

13. Haq Z, Khan W, Rizwan S. Advocacy, communication and social mobilisation for tuberculosis control in Pakistan: a qualitative case study. Int J Tuberc Lung Dis 2013; 17(3): 394-9.

14. Costa SM, Mendoza-Sassi, RA, Teixeira TP, Leivas VA, Cézar-VazMR. Conhecimento dos clientes com tuberculose pulmonar e seus familiares sobre adesão ao tratamento e fatores associados, no município do Rio Grande (RS). Ciênc Saúde Coletiva 2011; 16 (Suppl 1): 1427-35.

15. Freitas IM, Crispim JA, Pinto IC, Villa TCS, Brunello MEF, Pinto PFPS, et al. Conhecimento e percepção sobre tuberculose das famílias de pacientes em tratamento diretamente observado em um serviço de saúde de Ribeirão Preto-SP, Brasil. Texto Contexto Enferm 2012; 21(3): 642-9.

16. Queiroz AAR. O conhecimento e as atitudes das famílias de pacientes em tratamento da tuberculose na Atenção Primária à Saúde [dissertação de mestrado]. Natal: Universidade Federal do Rio Grande do Norte; 2012.

17. Kritski AL, Villa TS, Trajman A, Silva JRL, Medronho RA, Ruffino-Netto A. Duas décadas de pesquisa em tuberculose no Brasil: estado da arte das publicações científicas. Rev Saúde Pública 2007; 41(Suppl 1): 9-14.

18. Ferreira Junior S, Oliveira HB, Marin-Léon L. Conhecimento, atitudes e praticas sobre tuberculose em prisões e no serviço publico de saúde. Rev Bras Epidemiol 2013; 16(1): 100-13.

19. Ali SS, Rabbani F, Siddiqui UN, Zaidi AH, Sophie A, Virani SJ, et al. Tuberculosis: do we know enough? A study of patients and their families in an out-patient hospital setting in Karachi, Pakistan. Int J Tuberc Lung Dis 2003; 7(11): 1052-8.

20. Bolfarine H, Bussab WO. Elementos de Amostragem. São Paulo: Blucher; 2005.

21. World Health Organization (WHO). Advocacy, communication and social mobilization for TB control: a guide to developing knowledge, attitude and practice surveys. Geneva: WHO; 2008.

22. Brasil. Ministério da Saúde. Secretaria de Atenção à Saúde. Departamento de Atenção Básica. Vigilância em Saúde: dengue, esquistossomose, hanseníase, malária, tracoma e tuberculose. 2 edição. Revisada. Série A. Normas e Manuais Técnicos Cadernos de Atenção Básica - n 21. Brasília: Ministério da Saúde; 2008. 
23. Chang SH, Cataldo JK. A systematic review of global cultural variations in knowledge, attitudes and health responses to tuberculosis stigma. Int J Tuberc Lung Dis 2014; 18(2): 168-73.

24. Brasil. Ministério da Saúde. Secretaria de Vigilância em Saúde. Departamento de Vigilância Epidemiológica. Manual de Recomendações para o controle da Tuberculose no Brasil. Brasília: Ministério da Saúde; 2011.

25. Centers for Disease Control and Prevention (CDC). Guidelines for the investigation of contacts of persons with infectious tuberculosis: recommendations from the National Tuberculosis Controllers Association and CDC. MMWR 2005; 54 (RR15): 1-47.

26. Khan A, Walley J, Newell J, Imdad N. Tuberculosis in Pakistan: socio-cultural constraints and opportunities in treatment. Soc Sci Med 2000; 50(2): 247-54.

27. Lönnroth K1, Williams BG, Stadlin S, Jaramillo E, Dye C. Alcohol use as a risk factor for tuberculosis a systematic review. BMC Public Health 2008; 8: 289.

28. Harries AD, Zachariah R, Corbett EL, Lawn SD, Santos-Filho ET, Chimzizi R. The HIV-associated tuberculosis epidemic--when will we act? Lancet 2010; 375(9729): 1906-19.

29. Hargreaves JR, Boccia D, Evans CA, Adato M, Petticrew M, Porter JD. The social determinants of tuberculosis: from evidence to action. Am J Public Health 2011; 101(4): 654-62.

30. Brasil. Portal Brasil. Encerramento do Projeto Fundo Global TB - Brasil (FGTB). Disponível em: http: / / www.brasil.gov.br/saude/2011/06/ governo-analisa-a-possibilidade-de-deixar-de-usarrecursos-do-fundo-global-contra-aids. (Acessado em 10 de dezembro de 2014).

31. Organização Pan-Americana de Saúde (OPAS). Saúde nas Américas: panorama regional e perfis de países. Publicação Científica e Técnica No. 636. Washington, DC: OPAS; 2012. Disponível em: http:/ / bit.ly/Qz6C28. (Acessado em 01 de março de 2014).

32. Arcêncio RA, Oliveira MF, Cardozo-Gonzales RI, Ruffino-Netto A, Pinto IC, Villa TC. City tuberculosis control coordinators' perspectives of patient adherence to DOT in São Paulo State, Brazil, 2005. Int J Tuberc Lung Dis 2008; 12(5): 527-31.

33. Crispim JA, Fiorati RC, Queiroz AAR, Pinto IC, Palha PF, Arcêncio RA. Tuberculose no contexto das famílias: as vivências de familiares e pacientes acometidos pela doença. Rev Enferm 2013; 21 (1): 606-11.

34. Yadav SP, Mathur ML, Dixit AK. Knowledge and attitude towards tuberculosis among sandstone quarry workers in desert parts of Rajasthan. Indian J Tuberc 2006; 53:187-95.

35. Gelaw M, Genebo T, Dejene A, Lemma E, Eyob G. Attitude and social consequences of tuberculosis in Addis Ababa, Ethiopia. East Afr Med J 2001; 78(7): 382-8.

36. Russell E, Swanson RC, Atun R, Nishtar S, Chunharas S. Systems thinking for the post-2015 agenda. Lancet 2014; 383(9935): 2124-5.

Received on: 03/10/2014

Final version presented on: 07/15/2014

Accepted on: 09/25/2014 